\title{
Improving salt tolerance in Triticum aestivum (L.) plants irrigated with saline water by exogenously applied proline or potassium
}

\begin{abstract}
Exogenously appliedproline or potassium (K) ability to ameliorate the adverse influences of irrigation with saline $(\mathrm{NaCl} ; 120 \mathrm{mM})$ water in wheat plants (Triticumaestivum L.) was studied using a controlled pot experiment. Twenty-day-old plants were irrigated with saline water in combination with spraying plants with proline $(10 \mathrm{mM})$ or $\mathrm{K}\left(6 \mathrm{mM} \mathrm{K}_{2} \mathrm{O}\right.$ in $\mathrm{K}_{2} \mathrm{SO}_{4}$ ) until plants reached 50 days in old at which experiments were terminated. Except for increasing $\mathrm{K}^{+}$content and $\mathrm{K}^{+} / \mathrm{Na}^{+}$ratio with $\mathrm{K}$ application and elevating proline content with proline application, either proline or $\mathrm{K}$ foliar application not affected all other tested parameters. On the other hand, salt stress significantly reduced growth characteristics (length, fresh and dry weights of plant shoot), photosynthesis efficiency (chlorophylls and carotenoids contents, and performance index), $\mathrm{K}^{+}$content, $\mathrm{K}^{+} / \mathrm{Na}^{+}$ratio and catalase (CAT) activity, while significantly increased the contents of $\mathrm{Na}^{+}, \mathrm{C} 0$ and osmoprotectants and non-enzymatic antioxidants (free proline, total soluble sugars, ascorbic acid; AsA and glutathione; GSH), and the activity of antioxidant enzymes (superoxide dismutase; SOD, ascorbate peroxidase; APX and glutathione peroxidase; GPX). However, foliar application of proline or $\mathrm{K}$ for salt stressed plants alleviated the adverse effects of salt stress in wheat plants by increasing salt tolerance in plants through further increases in the activity of antioxidant enzymes and endogenous contents of proline and $\mathrm{K}$, in addition to recovering plant growth. The results of this study recommend using either proline or $\mathrm{K}$ as foliar spray to wheat plants when grown under salt stress conditions.
\end{abstract}

Keywords: Wheat, salinity, growth and yield, osmoprotestants, antioxidant enzyme
Volume 8 Issue 2 - 2018

\author{
Mostafa M Rady, Gamal F Mohamed \\ Department of Botany, Faculty of Agriculture, Fayoum University, \\ Egypt
}

Correspondence: Mostafa M Rady, Department of Botany, Faculty of Agriculture, 635।4 Fayoum, Egypt, Email mrady2050@gmail.com

Received: December 26, 2017 | Published: April 06, 2018

\section{Introduction}

High salinity induces physio-biochemical and molecular changes in plants, and causes serious impairments in the growth and productivity of crop plants Golldack et al.; ${ }^{1}$ Miranda et al. ${ }^{2}$ In plants, effects of salinity may arise from osmotic and ionic components, and overproduction of reactive oxygen species (ROS; $\mathrm{O}_{2}^{-},{ }^{-1} \mathrm{O}_{2}, \mathrm{OH}^{-}$, and $\mathrm{H}_{2} \mathrm{O}_{2}$ ) You\&Chan ${ }^{3}$ ROS cancause damage to biological membranes due to that they damage biological molecules (e.g., proteins and lipids) Abogadallah. ${ }^{4}$ Activation of several enzymes (e.g., superoxide dismutase; SOD, guaiacol peroxidase; GPX, catalase; CAT and ascorbate peroxidase; APX) protects cells and sub cellular compartments against ROS Foyer\&Noctor ${ }^{5}$ APX acts in downstream cascades leading to modulation of low molecular weight nonenzymatic antioxidants (e.g., ascorbate; AsA and glutathione; GSH) that are involved as a part of AsA-GSH cycle as a highly complex redox system. In addition, other molecules such as carotenoids and free proline may also alleviate oxidative damage Gill\&Tuteja; Rady et al. ${ }^{7}$ Crop plants are able to adapt to environmental stress conditions. Accumulations of organic solutes and/or control of ion movement to allow for high intracellular concentrations of solutes are of adaptation means. Salinity causes osmotic stress that limits water availability, thus, osmotic adjustment is an important feature to minimize dehydration in saline environments. Osmotic adjustment allows plants to maintain cell turgidity and physiological processes. It also includes compartmentalization of toxic ions (mainly $\mathrm{Na}^{+}$and $\mathrm{Cl}^{-}$) in vacuoles, and consequently reducing their cyto toxic effects Brini $\&$ Masmoud $^{8}$ and accumulation of low molecular weight compatible osmolyte in the cytosolic Chen \& Jiang ${ }^{9}$ These compatible osmolytes do not interfere with normal biochemical reactions Hussain et al. ${ }^{10}$ As one of the compatible osmolytes produced during stress, proline considers as a key signaling molecule able to triggering multiple responses and represents a part of the adaptation process. Studies report that proline accumulation is associated with osmotic adjustment and participates in stabilization of membranous protein, elimination of free radicals, cell signaling, and balance of redox and induction of gene expression Sobahan et al. ${ }^{11}$ Kavi Kishor \&Sreenivasulu ${ }^{12}$ Some studies have demonstrated that exogenous supplementation of proline at appropriate levels to plants exposed to stress conditions causes a preventive and/or recovery effect Yan et al.; ${ }^{13}$ Patade et al. ${ }^{14}$ Rady et al. ${ }^{7}$ Another one of the compatible osmolyte that should be foliarly added at appropriate levels during stress, potassium $(\mathrm{K})$ is the most considerable cation in plants and considered as one of the major essential nutrient elements for crop plant growth, development and yield, even though it is not an integral component or a structural part of the cellular organelles or the plant, respectively. $\mathrm{K}$ is associated or involved with many of the physiological process supporting plant growth and development. It is positively affected the water relations, photosynthesis, assimilate transport and enzyme activation. It has been reported that $\mathrm{K}$ regularizes physiological processes such as photosynthesis, translocation of cations into sink organs, regulation of turgor pressure and enzymes activation Mengel \& Kirkby; ${ }^{15} \mathrm{~A}$ bid et al. ${ }^{16}$ It has been reported that, it is not easy to completely correct $\mathrm{Na}^{+}$-induced $\mathrm{K}^{+}$deficiencies by the addition of $\mathrm{K}$ fertilizers to soil due to that $\mathrm{K}^{+}$in soil solution remains relatively low even after the addition of $\mathrm{K}$ fertilizer under field conditions Grattan \& Grieve. ${ }^{17}$ Therefore, foliar application of macro-nutrients is beneficial in overcoming nutritional deficiencies and in reducing the quantity of 
fertilizer applied to the soil, and it can be a complementary measure taken to provide nutrients during a critical phase of restricted nutrient supply Southwick et al.; ${ }^{18}$ Howard et a1. ${ }^{19}$ It has been also reported that foliar applied $\mathrm{K}$ can alleviate the adverse effects of salt stress on growth and yield of different crops and can correct the deficiency of $\mathrm{K}$ and improve the ratio of $\mathrm{K}^{+} / \mathrm{Na}^{+}$in salt stressed conditions Kaya et al.; ${ }^{20,21}$ Ahmad \& Jabeen. ${ }^{22}$ Hence, the present experimental study was designed to test the hypothesis that foliar spraying with proline or $\mathrm{K}$ was effective as an osmoprotectant and effective in reducing the adverse effects of salinity in wheat plants.

\section{Material and methods}

\section{Growth conditions and treatments}

A greenhouse pot experiment was conducted using wheat (Triticum aestivum L., cv. Giza 168) seeds that were surface sterilized in $0.1 \%$ $\mathrm{HgCl}_{2}$ for 1 minute and were then washed in sterilize-de ionized water. Plastic pots $(30-\mathrm{cm}$ diameter, $25-\mathrm{cm}$ depth) were filled with equal sand amounts. Using commercial acid, sand was previously was heat several times to remove all anions and cations, and was then washed with distilled water several times to remove the acid. In each pot, 20 seeds were sown, and pots $(n=120)$ were then arranged for growing plants in an open greenhouse for 3-repeated pot experiment. An average of $19 \pm 3 / 10 \pm 2{ }^{\circ} \mathrm{C}$ was the day/night temperatures, an average of $62.0-65.1 \%$ was the relative humidity, and an average of $10-11 \mathrm{~h}$ was the day length. $\mathrm{A}^{1} \mathrm{2}$-strength Hoagland's nutrient solution Hoagland\&Arnon ${ }^{23}$ was supplied at $100 \%$ field capacity (FC) every 2 days to all pots up to plants reached 20 days in old. Pots were then divided into 6 groups (treatments) each of 20 pots. In group 1, pots were irrigated with pure Hoagland's nutrient solution and plants were sprayed three times with water and expressed as a control. In groups 2 and 3, pots were irrigated with pure Hoagland's nutrient solution and plants were sprayed three times with proline $(10 \mathrm{mM})$ and $\mathrm{K}(6$ $\mathrm{mM} \mathrm{K}_{2} \mathrm{O}$ in $\mathrm{K}_{2} \mathrm{SO}_{4}$ ), respectively. In group 4, pots were irrigated with Hoagland's nutrient solution contained $\mathrm{NaCl}(120 \mathrm{mM})$ and plants were sprayed three times with water. In groups 5 and 6 pots were irrigated with Hoagland's nutrient solution contained $\mathrm{NaCl}(120 \mathrm{mM})$ and plants were sprayed three times with proline $(10 \mathrm{mM})$ and $\mathrm{K}(6$ $\mathrm{mM} \mathrm{K}_{2} \mathrm{O}$ in $\mathrm{K}_{2} \mathrm{SO}_{4}$ ), respectively. Plants were received 3 foliar sprays (e.g., at 21,31 and 41 days after sowing; DAS), and irrigation with Hoagland's nutrient solution contained $\mathrm{NaCl}(120 \mathrm{mM})$ for stress treatments was started at 21DAS up to the end of experiment (50DAS). The foliar spray solutions were prepared containing $0.1 \%$ Twenty 20 and provided to plant foliage to run-off. The $10 \mathrm{mMproline}$ and $6 \mathrm{mM}$ $\mathrm{K}_{2} \mathrm{O}$ in $\mathrm{K}_{2} \mathrm{SO}_{4}$, and 3 foliar sprays were selected for this study because they were greatly induced the best response of wheat seedling growth, and the selection of $120 \mathrm{mM} \mathrm{NaCl}$ was selected because it was greatly affected wheat seedling growth based on our preliminary studies (data not shown). All pots were arranged in a completely randomized design. Soil $\mathrm{pH}$ was adjusted back to the control $\mathrm{pH}$ of $6.0-6.2$ with diluted $\mathrm{H}_{2} \mathrm{SO}_{4}$. The experiment was repeated three times. Experiments were terminated after 50 DAS. The 50-d-old seedlings from each treatment were collected for various measurements.

\section{Material harvesting, growth and photosynthesis efficiency analyses}

The plant samples were harvested at 50 DAS, and a group of shoots of each treatment $(n=9)$ were separated to measure their lengths and fresh weights. Shoots were then oven-dried on $70^{\circ} \mathrm{C}$ for $48 \mathrm{~h}$ or up to a constant weight to record dry weights. The upper third leaf was separated from another group of shoots of each treatment $(n=9)$ and immediately frozen in liquid nitrogen. Thereafter, leaves were pulverized in a mortar and stored at $-25^{\circ} \mathrm{C}$ until analysis. Concentrations of leaf chlorophylls and carotenoids were assessed Arnon $^{24}$ in acetone extract by measuring with a UV-160A UV-vis Recording Spectrometer (Shimadzu, Japan) at 663, 645 and 470nm. Performance index (PI) of photosynthesis (chlorophyll a fluorescence) based on the equal absorption (PIABS) was calculated Clark et al. ${ }^{25}$

\section{Extraction and determination of inorganic and organic solutes}

To prepare extracts, incubation of $50 \mathrm{mg}$ of lyophilized powder from leaves was done with $5 \mathrm{ml}$ of de ionized water for $1 \mathrm{~h}$ in a water bath at $45^{\circ} \mathrm{C}$. The suspension was then centrifuged at $3,000 \times g$ for $10 \mathrm{~min}$ at $25^{\circ} \mathrm{C}$. The supernatant was collected and filtered through filter paper, and filtered supernatant was then stored at $-25^{\circ} \mathrm{C}$ until use. Contents of $\mathrm{Na}^{+}$and $\mathrm{K}^{+}$were determined Malavoltaet al. ${ }^{26}$ by flame photometry. Content of $\mathrm{Cl}^{-}$was determined using a spectrophotometric method with $\mathrm{NaCl}$ as a standard Gaines et al. ${ }^{27}$ Determinations of osmo protectants and non-enzymatic antioxidants contents Content of free proline concentration was determined Bates et al. ${ }^{28}$ in toluene phase produced from sulphosalicylic acid extract mixed with freshly prepared acid ninhydrin solution that was incubated in a water-bath at $90^{\circ} \mathrm{C}$ for $30 \mathrm{~min}$, and absorbance was read at $520 \mathrm{~nm}$. After extraction with $96 \%(\mathrm{v} / \mathrm{v})$ ethanol according to Irigoyen et al. ${ }^{29}$ total soluble sugars were measured by reacting $0.1 \mathrm{ml}$ of the ethanol extract with $3 \mathrm{ml}$ of freshly prepared enthrone reagent [150 $\mathrm{mg}$ an throne plus $100 \mathrm{ml}$ of $72 \%(\mathrm{v} / \mathrm{v})$ sulphuric acid] and then placed in a boiling water bath for $10 \mathrm{~min}$. After cooling, samples were read at $625 \mathrm{~nm}$ using a Bausch and Lomb-2000 Spectronic Spectrophotometer. Content of ascorbic acid (AsA) was determined using the method of Mukherjee \& Choudhuri ${ }^{30}$ Samples were extracted in $6 \%(\mathrm{w} / \mathrm{v})$ TCA, and the extracts were mixed with $2 \mathrm{ml}$ of $2 \%(\mathrm{w} / \mathrm{v})$ dinitrophenyl hydrazine (in acidic medium).Thereafter, 1 drop of $10 \%(\mathrm{w} / \mathrm{v})$ thiourea in $70 \%(\mathrm{v} / \mathrm{v})$ ethanol was added and the mixtures were boiled for $15 \mathrm{~min}$ in a water bath. After cooling, $5 \mathrm{ml}$ of $80 \%(\mathrm{v} / \mathrm{v}) \mathrm{H}_{2} \mathrm{SO}_{4}$ was added at $0^{\circ} \mathrm{C}$ and samples were read at $530 \mathrm{~nm}$. Content of glutathione (GSH) was determined using the method of $\mathrm{Griffth}^{31}$ in fresh leaf tissue that was homogenized in $2 \%(\mathrm{v} / \mathrm{v})$ metaphosphoric acid and centrifuged at $17,000 \times$ gfor $10 \mathrm{~min}$. The supernatant was neutralized by sodium citrate and each assay contained $700 \mu \mathrm{l}$ NADPH $(0.3 \mathrm{mM}), 100 \mu \mathrm{l}$

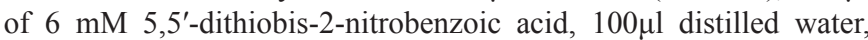
and $100 \mu \mathrm{l}$ of extract was stabilized at $25^{\circ} \mathrm{C}$ for $3-4 \mathrm{~min}$. Then $10 \mu \mathrm{l}$ of $50 \mathrm{units} \mathrm{ml}^{-1} \mathrm{GSH}$ reductase was added and the absorbance was recorded at $412 \mathrm{~nm}$.

\section{Antioxidant enzymes}

Enzyme extracts were prepared by homogenizing $200 \mathrm{mg}$ of lyophilized powder of leaves in a cold mortar with $2 \mathrm{ml}$ of $100 \mathrm{mM}$ potassium phosphate buffer at $\mathrm{pH} 7.0$, containing $0.1 \mathrm{mM}$ EDTA. For APX activity estimation, $2 \mathrm{mM}$ AsA was added to the extraction buffer. The homogenate was filtered through a nylon cloth and centrifuged at $12,000 \times g$ for $15 \mathrm{~min}$. All procedures were conducted at $4{ }^{\circ} \mathrm{C}$ and the extract was stored at $-25^{\circ} \mathrm{C}$ until analysis. Protein content in the extracts was measured according to Bradford ${ }^{32}$ Activity of SOD (EC 1.15.1.1) was determined by measuring its ability to inhibit the photochemical reduction of nitro blue tetra zolium (NBT) chloride, as described by Beauchamp \& Fridovich. ${ }^{33}$ One unit of SOD activity was defined as the amount of enzyme required to cause $50 \%$ inhibition of 
the NBT photo reduction rate, and the results were expressed as $\mathrm{U}$ $\mathrm{mg}^{-1}$ protein.CAT (EC 1.11.1.6) activity was determined according to Harvir \& Mac Hale ${ }^{34}$ by monitoring the decrease in absorbance at $240 \mathrm{~nm}$ due to $\mathrm{H}_{2} \mathrm{O}_{2}$ breakdown $\left(\varepsilon=36 \mathrm{M}^{-1} \mathrm{~cm}^{-1}\right)$. Activity of APX (1.11.1.11) was determined according to the method described by Nakano\&Asada ${ }^{35}$ by monitoring the oxidation of AsA, which was measured as the decrease in absorbance at $290 \mathrm{~nm}\left(\varepsilon=2.8 \times 10^{-3}\right.$ $\mathrm{M}^{-1} \mathrm{~cm}^{-1}$ ). Activity of GPX (EC 1.11.1.9) was assayed according to Kar \& Mishra $^{36}$ by monitoring the increase in absorbance at $470 \mathrm{~nm}$ due to formation of tetra guaiacol $\left(\varepsilon=26.6 \times 10^{-3} \mathrm{M}^{-1} \mathrm{~cm}^{-1}\right)$. Activities of CAT, APX and GPX were expressed as $\mu \mathrm{mol} \mathrm{H}_{2} \mathrm{O}_{2} \mathrm{~min}^{-1} \mathrm{mg}^{-1}$ protein (DW).

\section{Statistical analysis}

The experimental design was completely randomized design. The results were subjected to one-way analysis of variance (ANOVA) to evaluate the significance of differences between treatments $(P \leq 0.05)$.

\section{Results}

Data in Tables 1-5 reveal that, except for the increase of $\mathrm{K}^{+}$content and $\mathrm{K}^{+} / \mathrm{Na}^{+}$ratio with $\mathrm{K}$ foliar application in addition to elevation of proline content with proline foliar application, either $\mathrm{K}$ or proline foliar application found to not affect the all other tested parameters. $\mathrm{NaCl}(120 \mathrm{mM}$, salt stress) treatment significantly reduced growth characteristics (shoot length by $17.7 \%$, shoot fresh weight by $39.6 \%$, and shoot dry weight by $39.5 \%$; (Table 1 ), photosynthesis efficiency (total chlorophylls content by $62.4 \%$, total carotenoids content by $42.6 \%$, and performance index by $44.1 \%$; Table 2 ), $\mathrm{K}^{+}$content by $36.1 \%$

and $\mathrm{K}^{+} / \mathrm{Na}^{+}$ratio by $74.6 \%$ (Table 3 ), and catalase (CAT) activity by $31.5 \%$ (Table 4 ), while significantly increased $\mathrm{Na}^{+}$content by $151.6 \%$ and $\mathrm{Cl}^{-}$content by $111.1 \%$ (Table 3 ), and osmoprotectants and nonenzymatic antioxidants contents (free proline by $40.3 \%$, total soluble sugars by $75.0 \%$, ascorbic acid; AsA by $131.1 \%$ and glutathione; GSH by $122.8 \%$; Table 4 ), and the activities of antioxidant enzymes (superoxide dismutase; SOD by $54.0 \%$, ascorbate peroxidase; APX by $50.0 \%$, and glutathione peroxidase; GPX by $38.5 \%$; Table 5 ). However, application of proline or $\mathrm{K}$ to salt stressed plants alleviated the adverse effects of salt stress in wheat plants by increasing salt tolerance in plants via further increasing the activity of antioxidant enzymes and their endogenous contents, in addition to recovering plant growth. Foliar application of proline or K significantly increased shoot length by 12.4 or $13.0 \%$, shoot fresh weight by 36.8 or $40.2 \%$, shoot dry weight by 34.6 or $38.5 \%$, total chlorophylls content by 79.5 or $100.0 \%$, total carotenoids content by 51.3 or $56.4 \%$, PI by 44.2 or $50.0 \%, \mathrm{~K}^{+}$content by 19.6 or $41.3 \%, \mathrm{~K}^{+} / \mathrm{Na}^{+}$ratio by 92.4 or $162.7 \%$, proline content by $38.5 \%$ or not affected, SOD activity by 14.1 or $11.7 \%$, CAT activity by 47.9 or $45.8 \%$, APX activity by 21.4 or $18.5 \%$, and GPX activity by 27.2 or $23.2 \%$, respectively, while significantly decreased $\mathrm{Na}^{+}$content by 37.2 or $46.2 \%$, and $\mathrm{Cl}^{-}$content by 23.7 or $36.8 \%$, respectively compared to salt-stressed plants sprayed with water only. These results revealed that, even though significant increases in growth characteristics, photosynthetic efficiency and $\mathrm{K}$ content of salt-stressed plants were exhibited by the foliar spray with proline or $\mathrm{K}$, these improved parameters not reached their levels of non-stressed control plants sprayed with water only. Also, foliar spray with $\mathrm{K}$ was more effective than foliar spray with proline under salt stress conditions.

Table I Effect of proline ( $10 \mathrm{mM})$ or $\mathrm{K}\left(6 \mathrm{mM} \mathrm{K}_{2} \mathrm{O}\right.$ in $\left.\mathrm{K}_{2} \mathrm{SO}_{4}\right)$ foliar spray applications on growth traits of wheat plants irrigated with saline water

\begin{tabular}{llll}
\hline & Parameter & & \\
Treatments & Shoot length $(\mathbf{c m})$ & Shoot fresh weight $(\mathbf{g})$ & Shoot dry weight $\mathbf{( g )}$ \\
Water (Control) & $68.4 \pm 5.8 \mathrm{ab}$ & $14.4 \pm 1.1 \mathrm{a}$ & $4.3 \pm 0.3 \mathrm{a}$ \\
Proline & $68.8 \pm 5.7 \mathrm{ab}$ & $14.7 \pm 1.2 \mathrm{a}$ & $4.4 \pm 0.3 \mathrm{a}$ \\
K & $72.6 \pm 6.4 \mathrm{a}$ & $15.2 \pm 1.4 \mathrm{a}$ & $4.6 \pm 0.4 \mathrm{a}$ \\
Salinity & $56.3 \pm 5.2 \mathrm{c}$ & $8.7 \pm 0.9 \mathrm{c}$ & $2.6 \pm 0.2 \mathrm{c}$ \\
Salinity+ Proline & $63.3 \pm 5.7 \mathrm{~b}$ & $11.9 \pm 1.0 \mathrm{~b}$ & $3.5 \pm 0.2 \mathrm{~b}$ \\
\hline Salinity +K & $63.6 \pm 5.4 \mathrm{~b}$ & $12.2 \pm 1.1 \mathrm{~b}$ & $3.6 \pm 0.3 \mathrm{~b}$ \\
\hline
\end{tabular}

Means followed by the same letter in each column are not significantly different according to the LSD test $(P \leq 0.05)$.

Table 2 Effect of proline $(10 \mathrm{mM})$ or $\mathrm{K}\left(6 \mathrm{mM} \mathrm{K}_{2} \mathrm{O}\right.$ in $\left.\mathrm{K}_{2} \mathrm{SO}_{4}\right)$ foliar spray applications on photosynthetic pigments and efficiency (PI, performance index) of wheat plants irrigated with saline water

\begin{tabular}{llll}
\hline Treatments & Parameter & & \\
& Total chlorophylls $\left(\mathbf{m g ~ g}^{-1} \mathbf{~ F W}\right)$ & Total carotenoids & PI \\
Water (Control) & $1.94 \pm 0.05 \mathrm{a}$ & $\left(\mathrm{mg} \mathrm{g}{ }^{-1} \mathrm{FW}\right)$ & $(\%)$ \\
Proline & $1.98 \pm 0.06 \mathrm{a}$ & $0.68 \pm 0.02 \mathrm{a}$ & $9.3 \pm 0.2 \mathrm{a}$ \\
K & $2.06 \pm 0.07 \mathrm{a}$ & $0.67 \pm 0.02 \mathrm{a}$ & $9.4 \pm 0.2 \mathrm{a}$ \\
Salinity & $0.73 \pm 0.03 \mathrm{c}$ & $0.69 \pm 0.02 \mathrm{a}$ & $9.6 \pm 0.3 \mathrm{a}$ \\
Salinity + Proline & $1.31 \pm 0.04 \mathrm{~b}$ & $0.39 \pm 0.01 \mathrm{c}$ & $5.2 \pm 0.1 \mathrm{c}$ \\
\hline Salinity + K & $1.46 \pm 0.04 \mathrm{~b}$ & $0.59 \pm 0.01 \mathrm{l}$ & $7.5 \pm 0.2 \mathrm{~b}$ \\
\hline
\end{tabular}

Means followed by the same letter in each column are not significantly different according to the LSD test (PS 0.05).

Citation: Rady MM, Mohamed GF. Improving salt tolerance in Triticumaestivum (L.) plants irrigated with saline water by exogenously appliedproline or potassium. Adv Plants Agric Res. 2018;8(2):193-199. DOI: 10.15406/apar.2018.08.00312 
Table 3 Effect of proline $(10 \mathrm{mM})$ or $\mathrm{K}\left(6 \mathrm{mM} \mathrm{K}_{2} \mathrm{O}\right.$ in $\left.\mathrm{K}_{2} \mathrm{SO}_{4}\right)$ foliar spray applications on $\mathrm{K}, \mathrm{Na}$ and $\mathrm{Cl}$ contents, and $\mathrm{Na}+/ \mathrm{K}+$ ratio in the leaves and roots of wheat plants irrigated with saline water

\begin{tabular}{lllll}
\hline Treatments & $\begin{array}{l}\text { Parameter } \\
\mathbf{K}^{+}\end{array}$ & $\mathbf{N a}^{+}$ & $\mathbf{C l}^{-}$ & \\
& $\left.\mathbf{( m g ~ g}{ }^{-1} \mathbf{~ D W}\right)$ & $\mathbf{( \mathbf { m g ~ g } ^ { - 1 } \mathbf { ~ D W } )}$ & $\mathbf{( \mathbf { m g ~ g } ^ { - 1 } \mathbf { ~ D W } )}$ & $\mathbf{N a}^{+} / \mathbf{K}^{+}$ratio \\
\hline Water (Control) & $1.44 \pm 0.04 \mathrm{~b}$ & $0.31 \pm 0.00 \mathrm{de}$ & $0.18 \pm 0.00 \mathrm{e}$ & $4.65 \pm 0.15 \mathrm{~b}$ \\
Proline & $1.42 \pm 0.05 \mathrm{~b}$ & $0.30 \pm 0.00 \mathrm{e}$ & $0.18 \pm 0.00 \mathrm{e}$ & $4.73 \pm 0.14 \mathrm{~b}$ \\
K & $1.72 \pm 0.05 \mathrm{a}$ & $0.28 \pm 0.00 \mathrm{e}$ & $0.17 \pm 0.00 \mathrm{e}$ & $6.14 \pm 0.20 \mathrm{a}$ \\
Salinity & $0.92 \pm 0.03 \mathrm{e}$ & $0.78 \pm 0.01 \mathrm{a}$ & $0.38 \pm 0.00 \mathrm{a}$ & $1.18 \pm 0.06 \mathrm{e}$ \\
Salinity + Proline & $1.10 \pm 0.04 \mathrm{~d}$ & $0.49 \pm 0.01 \mathrm{~b}$ & $0.29 \pm 0.00 \mathrm{~b}$ & $2.27 \pm 0.09 \mathrm{~d}$ \\
\hline Salinity + K & $1.30 \pm 0.04 \mathrm{c}$ & $0.42 \pm 0.00 \mathrm{c}$ & $0.24 \pm 0.00 \mathrm{c}$ & $3.10 \pm 0.11 \mathrm{c}$ \\
\hline
\end{tabular}

Means followed by the same letter in each column are not significantly different according to the LSD test $(P \leq 0.05)$.

Table 4 Effect of proline ( $10 \mathrm{mM})$ or $\mathrm{K}\left(6 \mathrm{mM} \mathrm{K} \mathrm{O}_{2}\right.$ in $\left.\mathrm{K}_{2} \mathrm{SO}_{4}\right)$ foliar spray applications on proline, total soluble sugars, ascorbic acid (AsA) and glutathione (GSH) contents in the leaves and roots of wheat plants irrigated with saline water.

\begin{tabular}{lllll}
\hline & Parameter & & \\
Treatments & Free proline $\left(\mu \mathrm{mol} \mathrm{g}{ }^{-1} \mathrm{DW}\right)$ & Soluble sugars & AsA & GSH \\
\hline & & $\left(\mathrm{mg} \mathrm{g}^{-1} \mathrm{DW}\right)$ & $\left(\mu \mathrm{mol} \mathrm{g}^{-1} \mathrm{FW}\right)$ & $\left(\mu \mathrm{mol} \mathrm{g}^{-1} \mathrm{FW}\right)$ \\
Water (Control) & $2.48 \pm 0.05 \mathrm{c}$ & $12.8 \pm 0.3 \mathrm{~b}$ & $1.22 \pm 0.02 \mathrm{~b}$ & $1.14 \pm 0.02 \mathrm{~b}$ \\
Proline & $3.42 \pm 0.08 \mathrm{~b}$ & $12.9 \pm 0.4 \mathrm{~b}$ & $1.24 \pm 0.02 \mathrm{~b}$ & $1.13 \pm 0.02 \mathrm{~b}$ \\
$\mathrm{~K}$ & $2.50 \pm 0.06 \mathrm{c}$ & $13.1 \pm 0.4 \mathrm{~b}$ & $1.22 \pm 0.02 \mathrm{~b}$ & $1.15 \pm 0.02 \mathrm{~b}$ \\
Salinity & $3.48 \pm 0.09 \mathrm{~b}$ & $22.4 \pm 0.5 \mathrm{a}$ & $2.82 \pm 0.03 \mathrm{a}$ & $2.54 \pm 0.04 \mathrm{a}$ \\
Salinity + Proline & $4.82 \pm 0.1 \mathrm{la}$ & $22.8 \pm 0.5 \mathrm{a}$ & $2.90 \pm 0.03 \mathrm{a}$ & $2.54 \pm 0.04 \mathrm{a}$ \\
\hline Salinity + K & $3.46 \pm 0.08 \mathrm{~b}$ & $22.8 \pm 0.5 \mathrm{a}$ & $2.88 \pm 0.03 \mathrm{a}$ & $2.55 \pm 0.05 \mathrm{a}$ \\
\hline
\end{tabular}

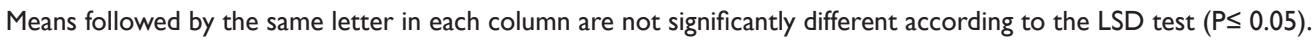

Table 5 Effect of proline ( $10 \mathrm{mM})$ or $\mathrm{K}\left(6 \mathrm{mM} \mathrm{K} \mathrm{O}_{2}\right.$ in $\left.\mathrm{K}_{2} \mathrm{SO}_{4}\right)$ foliar spray applications on superoxide dismutase (SOD), catalase (CAT), ascorbate peroxidase $(A P X)$ and glutathione peroxidase (GPX) activities in the leaves and roots of wheat plants irrigated with saline water

\begin{tabular}{|c|c|c|c|c|}
\hline \multirow[b]{2}{*}{ Treatments } & \multicolumn{4}{|l|}{ Parameter } \\
\hline & SOD & CAT & APX & GPX \\
\hline & (UA g grotein) & ( $\mu \mathrm{mol} \mathrm{H}_{2} \mathrm{O}_{2} \mathrm{~min}^{-1} \mathrm{~g}^{-1}$ protein) & ( $\mu \mathrm{mol} \mathrm{H}_{2} \mathrm{O}_{2} \mathrm{~min}^{-1} \mathrm{~g}^{-1}$ protein) & $\begin{array}{l}\left(\mu \mathrm{mol} \mathrm{H}_{2} \mathrm{O}_{2} \min ^{-1}\right. \\
\left.\mathrm{g}^{-1} \text { protein }\right)\end{array}$ \\
\hline Water (Control) & $3650 \pm 72 d$ & $178.8 \pm 3.4 \mathrm{a}$ & $11.2 \pm 0.2 \mathrm{~d}$ & $21.8 \pm 0.3 d$ \\
\hline Proline & $3720 \pm 75 d$ & $180.2 \pm 3.6 \mathrm{a}$ & $11.5 \pm 0.2 \mathrm{~d}$ & $21.6 \pm 0.3 d$ \\
\hline K & $3680 \pm 74 d$ & $|79.| \pm 3.5 a$ & $11.2 \pm 0.2 \mathrm{~d}$ & $21.2 \pm 0.3 d$ \\
\hline Salinity & $5620 \pm 108 c$ & $122.5 \pm 2.4 \mathrm{~b}$ & $16.8 \pm 0.3 c$ & $30.2 \pm 0.4 c$ \\
\hline Salinity + Proline & $6410 \pm 122 b$ & $181.2 \pm 3.5 a$ & $20.4 \pm 0.4 b$ & $38.4 \pm 0.6 b$ \\
\hline Salinity + K & $6280 \pm 116 b$ & $178.6 \pm 3.4 \mathrm{a}$ & $19.9 \pm 0.4 b$ & $37.2 \pm 0.5 b$ \\
\hline
\end{tabular}

Means followed by the same letter in each column are not significantly different according to the LSD test (PS 0.05).

\section{Discussion}

In the present study, foliar spraying of $10 \mathrm{mM}$ proline or $6 \mathrm{mM} \mathrm{K}$ $\left(\mathrm{K}_{2} \mathrm{O}\right.$ in $\left.\mathrm{K}_{2} \mathrm{SO}_{4}\right)$ to wheat plants was effective in reducing the effects of irrigation with saline water on plant growth (Table 1). Several researchers have reported the positive role of exogenous proline or $\mathrm{K}$ in ameliorating the deleterious effects of salinity in the growth of numerous plant species Kaya et al.a,b; ${ }^{37,20}$ Ahmad and Jabeen ${ }^{22}$ Huang et al. ${ }^{38} \mathrm{~A}$ gami $;{ }^{39}$ Teh et al. ${ }^{40} \mathrm{Wu}$ et al. ${ }^{41}$ To clarify the useful action of exogenous proline or $\mathrm{K}$ on growth, physio-biochemical and antioxidant defense system analyses were carried out using wheat leaves. Accumulation of $\mathrm{NaCl}$ in plant tissues decreases plant growth on saline conditions. By analyzing inorganic solutes, it was found that exogenous proline or $\mathrm{K}$ confer red useful effects by decreasing 
the accumulation of toxic ions $\left(\mathrm{Na}^{+}\right.$and $\left.\mathrm{Cl}^{-}\right)$and increasing proline, soluble sugars and $\mathrm{K}^{+}$contents in leaves of wheat plants under salt stress (Table 3) (Table 4). The decreased accumulation of $\mathrm{Na}^{+}$and $\mathrm{Cl}^{-}$in plants under salt stress as a result of proline or Kapplication was observed herein and also reported in many works Kaya et al.; ${ }^{33}$ Akram \& Ashraf; ${ }^{42}$ Huang et al. ${ }^{43}$ Nounjan et al. ${ }^{44}$ In ionic state, $\mathrm{K}^{+}$ is an important nutrient that maintains the plant cell turgidity and excess sodium in the soil results in a decrease in the absorption and translocation of mineral nutrients, especially $\mathrm{K}^{+}$Wang et al. ${ }^{45}$

Available $\mathrm{K}^{+}$content is reduced under saline conditions due to direct competition with $\mathrm{Na}^{+}$for charge-dependent binding sites during ion transport beyond the passive absorption of $\mathrm{K}^{+}$that occurs as a result of small differences in electro-chemical potential Chen et al. ${ }^{46}$ However, exogenous proline reduced $\mathrm{NaCl}$-induced $\mathrm{K}^{+}$efflux in plant roots Cuin \& Shabala ${ }^{47}$ in addition to increasing endogenous $\mathrm{K}^{+}$as a result of $\mathrm{K}$ foliar application as observed in the present work (Table 3). This finding would suggest that proline or $\mathrm{K}$ application may act in order to avoid $\mathrm{Na}^{+}$xylem loading as well as efficiently compartmentalizing $\mathrm{Na}^{+}$excess allowing a greater influx of $\mathrm{K}^{+}$to the leaves Assahaet al. ${ }^{48}$ Kaya et al..$^{21}$ \& Ben Ahmed et al. ${ }^{49}$ confirmed that $\mathrm{Na}^{+}$content is reduced in plants treated with proline or $\mathrm{K}$; it was demonstrated that proline was able to exclude $\mathrm{Na}^{+}$from the xylem sap preventing the transport of $\mathrm{Na}^{+}$to shoot, as well as $\mathrm{K}^{+}$is capable to antagonist $\mathrm{Na}^{+}$preventing it to accumulate in plant cells. The preservation of cytosolic $\mathrm{K}^{+} / \mathrm{Na}^{+}$ratio is a key role in plant tolerance to salinity; $\mathrm{K}^{+}$participates in a vast of physiological functions in plants, and $\mathrm{K}^{+}$deficiency becomes severe under salt stress leading to growth impairment Cuin \& Shabala. ${ }^{46}$

As of our data, the exogenous application of proline or $\mathrm{K}$ increased the $\mathrm{K}^{+} / \mathrm{Na}^{+}$ratio in the leaves of wheat plants, with significant advantage of $\mathrm{K}$ application (Table 3 ). Nounjan \& Theerakulpisut ${ }^{44}$ have observed that the addition of proline to the nutrient solution at $10 \mathrm{mM}$ affected the recovery period of rice plants exposed to 6 days of salinity; the $\mathrm{K}^{+} / \mathrm{Na}^{+}$ratio was greater in proline-treated plants than in those where proline was not applied. Similar result was reported by Kaya et al. ${ }^{21}$ applying proline or $\mathrm{K}$ on Cucumismelo plants. Regarding plant physiological responses to salt stress, the effect on photosynthetic efficiency (chlorophylls and carotenoids contents, and performance index; PI of chlorophyll "a") can be observed regarding responses to osmotic effects of NaCl-salt stress. Damaging the photosynthetic apparatus under salt stress as shown herein (Table 2) was a confirmation of Rong-Hua et al..$^{50}$ results. However, foliar application of $10 \mathrm{~m} \mathrm{M}$ proline or $6 \mathrm{mM} \mathrm{K}$ caused significant increases in photosynthetic pigments and PI in salt-stressed wheat plants. This improved efficiency of photosynthetic pigments may be attributed to stimulating chlorophyll biosynthesis and/or inhibiting its degradation, as well as the more efficient scavenging of ROS and stabilizing photosynthetic reactions by proline and other antioxidant compounds Abdelhamid et al. ${ }^{51}$ along with the osmo protectant effect of increased $\mathrm{K}$ in plants and its role in cell turgor to maintain cell metabolic processes. Wheat plants treated with proline or $\mathrm{K}$ showed a remarkable increase in the proline and $\mathrm{K}^{+}$content sunder salt treatment (Table 3) (Table 4), suggesting that these increased proline and $\mathrm{K}$ contents as effective osmoprotectants were possibly used to reduce the saline effects directly or providing an additional $\mathrm{N}$ source and $\mathrm{K}^{+}$ions to the plant. Of the potential mechanisms to tolerate salt stress by proline is the capacity for osmotic adjustment, which allows growth to continue under saline conditions Heuer ${ }^{52}$ Salinity treatment
$(120 \mathrm{mM} \mathrm{NaCl})$ resulted in a significant accumulation of proline in wheat plants. Proline accumulation, in response to stress, may play a role in stress adaptation within the cell Ashraf \& Foolad ${ }^{53}$ Evidence for the transport of proline to the root tip, where it accumulates during stress, has been reported. The rapid accumulation of amino acids, especially free proline during salinity stress suggests that these compounds may be acting as sinks for excess $\mathrm{N}$ in relation to the decreased growth occurring during the imposed stress Dubey \& Pessarakli ${ }^{54}$ They also play a role in osmotic adjustment, and serve as available sources of carbon and N Zhang et al..$^{55}$ This availability could be of special interest at after-stress recovery Verma ${ }^{56}$ On the other hand, application of $6 \mathrm{~m} \mathrm{MK}$ increased the endogenous $\mathrm{K}$ content (Table 3) for the sake of plant water status of salt stressed plants due to it is an important osmolyte. These solutes (proline and $\mathrm{K}$ ) probably provide protection against destabilization of proteins and membranes Zhao et al. ${ }^{57}$ Plants generate ROS continuously as a product of various metabolic path ways and oxidative stress was generated on account of excess salt. Low oxidative damage in proline- or K-treated stressed plants was harmonious with increased contents of ascorbic acid (AsA) and glutathione (GSH), and activation of CAT, SOD, APX and GPX enzymes under salinity (Table 4) (Table 5). Several reports have shown that CAT is the main scavenger of ROS in leaves, playing an important role in oxidative protection by eliminating $\mathrm{H}_{2} \mathrm{O}_{2}$, producing $\mathrm{H}_{2} \mathrm{O}$ and $\mathrm{O}_{2}$. CAT is found exclusively in peroxisomes and glyoxysomes and may prevent the formation of hydroxyl radicals that are responsible for lipid peroxidation of cell membranes and drastic effects on plant growth Abogadallah. ${ }^{4}$ In the present study, treatment of wheat plants with exogenous proline or $\mathrm{K}$ was effective in activating CAT activity (reduced under salt stress), thus, preventing oxidative damage in plant tissues. SOD is an important enzyme of the antioxidant system that converts superoxide into $\mathrm{H}_{2} \mathrm{O}_{2}$ and water, and is considered the first line of defense against ROS. It presents in chloroplasts, mitochondria, cytoplasm, apoplasts and peroxisomes Abogadallah. ${ }^{4}$

Herein (our results), SOD activity was increased by salt stress in leaves of wheat plants; this increase was further increased by exogenous proline or $\mathrm{K}$, evidencing the protective role of SOD for biological systems. Like CAT, APX removes $\mathrm{H}_{2} \mathrm{O}_{2}$, and increases in its activity due to salinity have also been observed (Chen and Jiang, 2010). AsA is the APX substrate which is oxidized to mono dehydroascorbate, which can be either enzymatically reconverted to AsA or converted to dehydroascorbate (DHA). DHA, in turn, can be oxidized to AsA using GSH as a reducing agent, being converted to GSSG which, in turn, is re-reduced during the cycle Valero et al. ${ }^{58}$ The balance of the AsAGSH pool must be strictly adjusted together with an adequate activity of APX, improving the antioxidant capacity of plant cells and avoiding oxidative damage Foyer \& Noctor ${ }^{5}$ Our results are clear evidence that exogenous proline or $\mathrm{K}$ efficiently activates both the non-enzymatic and enzymatic antioxidant systems (Table 4) (Table 5). In light of the above results, it has been concluded that foliar spraying with proline or $\mathrm{K}$ was effective in reducing the deleterious effects of salinity. Our results exhibited that exogenous proline or $\mathrm{K}$ acts by modifying the toxic ions content. In addition, the contribution of proline or $\mathrm{K}$ was effective in reducing oxidative damage by modulating the enzymatic and non-enzymatic antioxidant systems. These results of our study revealed that, even though significant improvements in the all assessed growth traits, physio-biochemical attributes and antioxidant defense systems were exhibited by the foliar spray with proline or K. Even, foliar spray with $\mathrm{K}$ was more effective than foliar spray with proline under salt stress conditions. 


\section{Conclusion}

From results of this study, it can be concluded that exogenous application of proline $(10 \mathrm{mM})$ or $\mathrm{K}(6 \mathrm{mM})$, used as foliar spray solution, could alleviate the harmful effects of $120 \mathrm{mM} \mathrm{NaCl}$ stress in wheat plants. Proline or $\mathrm{K}$ application improved the contents of leaf photosynthetic pigments and photosynthetic efficiency, the anti oxidative defense systems (i.e., enzymatic and non-enzymatic antioxidants) and the content of $\mathrm{K}+$, and reduced the content of $\mathrm{Na}+$, which reflects in improving wheat plant growth under $\mathrm{NaCl}$ stress. Generally, K application was more pronounced and effective than proline application.

\section{Acknowledgment}

None.

\section{Conflict of interest}

None.

\section{References}

1. Golldack D, Li C, Mohan H, et al. Tolerance to drought and salt stress in plants: unraveling the signaling networks. Front Plant Sci. 2014;5:1-10.

2. Miranda RS, Gomes-Filho E, Prisco JT, et al. Ammonium improves tolerance to salinity stress in Sorghum bicolor plants. Plant Growth Regul. 2016;78(1):121-131

3. You J, Chan Z. ROS regulation during abiotic stress responses in crop plants. Front Plant Sci. 2015;8(6):1092.

4. Abogadallah GM. Antioxidative defense under salt stress. Plant Signal Behav. 2010;5(4):369-374.

5. Foyer $\mathrm{CH}$, Noctor G. Ascorbate and Glutathione: The heart of the redox hub. Plant Physiol. 2011;155:2-18.

6. Gill SS, Tuteja N. Reactive oxygen species and antioxidant machinery in abiotic stress tolerance in crop plants. Plant Physiol Biochem. 2010;48(12):909-930.

7. Rady MM, Taha RS, Mahdi AHA. Proline enhances growth, productivity and anatomy of two varieties of Lupinustermis L. grown under salt stress. S Afr J Bot. 2016;102:221-227.

8. Brini $\mathrm{F}$, Masmoudi $\mathrm{K}$. Ion transporters and abiotic stress tolerance in plants. ISRN Molec Biol. 2012;1-13.

9. Chen H, Jiang JG. Osmotic adjustment and plant adaptation to environmental changes related to drought and salinity. Environ Rev 2010;18(1):309-319.

10. Hussain K, Majeed A, Nawaz K, et al. Effect of different levels of salinity on growth and ion contents of black seeds (Nigella sativa L.). Current Research Journal of Biological Sciences.2009;1(3):135-138.

11. Sobahan MA, Akter N, Ohno M Okuma, et al. Effects of exogenous proline and glycine betaine on the salt tolerance of rice cultivars. Biosci. Biotechnol. Biochem .2012;76(8):1568-1570.

12. Kavi Kishor PB, Sreenivasulu N. Is proline accumulation per se correlated with stress tolerance or is proline homeostasis a more critical issue? Plant Cell Environ. 2014;37(2):300-311.

13. Yan Z, Guo S, Shu S, Sun J, Tezuka T. Effects of proline on photosynthesis, root reactive oxygen species (ROS) metabolism in two melon cultivars (Cucumismelo L.) under $\mathrm{NaCl}$ stress. Afr J Biotechnol. 2011;10(80):18381-18390.
14. Patade VY, Lokhande VH, Suprasanna P. Exogenous application of proline alleviates salt Induced oxidative stress more efficiently than glycine betaine in sugarcane cultured cells. Sugar Tech. 2013;16(1):22-29.

15. Mengel K, Kirkby EA. Principles of plant nutrition. $5^{\text {th }}$ ed. Dordrecht: Kluwer Academic Publishers; 2001.

16. Abid AA, Mozammil H, Hafiz Saqib KT, et al. Foliar spray surpasses soil application of potassium for maize production under rainfed conditions Turk J Field Crops. 2016;21(1):36-43.

17. Grattan SR, Grieve CM. Mineral nutrient acquisition and response by plants grown in saline environments. In: Pessarakli M, editor. Plant and Crop Stress. Marcel Dekker: NewYork; 1999. p. 203-226.

18. Southwick SM, Olson W, Yeager J, et al. Optimum timing of potassium nitrate spray application to "French" prune trees. Journal of the American Society for Horticultural Science. 1996;121(2):326-333.

19. Howard DD, Gwathmey CO, Sams CE. Foliar feeding of cotton: Potassium sources, potassium solution buffering, and boron. J Agron. 1998;90:740-746.

20. Kaya C, Kirnak H, Higgs D. Enhancement of growth and normal growth parameters by foliar application of potassium and phosphorus on tomato cultivars grown at high salinity (NaCl). J Plant Nutr. 2001;24(2):357-367.

21. Kaya C, Tuna AL, Ashraf M, et al. Improved salt tolerance of melon (Cucumismelo L.) by the addition of proline and potassium nitrate. Environ Exp Bot. 2007;60:397-403.

22. Ahmad R, Jabeen R. Foliar spray of mineral elements antagonistic to sodium a technique to induce salt tolerance in plants growing under saline conditions. Pak J Bot. 2005;37(4):913-920.

23. Hoagland DR, Arnon DI. The water-culture method for growing plants without soil. Circular 347, University of California College of Agriculture, Berkeley, 1938

24. Arnon DI. Copper enzymes in isolated chloroplasts.Polyphenol oxidase in Beta vulgaris L. Plant Physiol. 1949;24(1):1-5.

25. Clark AJ, Landolt W, Bucher JB, et al. Beech (Fagussylvatica)response to ozone exposure assessed with a chlorophyll a fluorescence performance index. Environ Pollut .2000;109(3):501-507.

26. Malavolta E, Vitti GC, Oliveira SA. Avaliação do estudo nutricional das plantas, princípios e aplicações. Associação Brasileira para Pesquisa da Potassa e do Fosfato, 1989; p.201.

27. Bates LS, Waldren RP, Teare ID. Rapid determination of free proline for water-stress studies. Plant Soil. 1973;39(1):205-207.

28. Gaines MTP, Parker MB, Gascho GJ. Automated determination of chlorides in soil and plant tissue by sodium nitrate. Agron J. 1984;76:371374.

29. Irigoyen JJ, Emerich DW, Sanchez-Diaz M. Water stress induced changes in the concentrations of proline and total soluble sugars in nodulated alfalfa (Medicago sativa) plants. Physiol Plant. 1992;8(1):455-460.

30. Mukherjee SP, Choudhari MA. Implications of water stress induced changes in the levels of endogenous ascorbic acid and hydrogen peroxide in Vigna seedlings. Physiol Plant. 1983;58(2):116-170.

31. Griffth OW. Determination of glutathione and glutathione disulfide using glutathione reductase and 2 vinylpyridine. Anal Biochem. 1980;106(1):207-212.

32. Bradford MM. A rapid and sensitive method for the quantitation of microgram quantities of protein utilizing the principle of protein-dye binding. Anal Biochem. 1976;72:248-254. 
33. Beauchamp C, Fricovich I. Superoxide dismutase: improved assays and na assay applicable to acrylamide gels. Anal Biochem. 1971;44(1):276287.

34. Havir EA, McHale NA. Biochemical and developmental characterization of multiple forms of catalase in tobacco leaves. Plant Physiol. $1987 ; 84(2): 450-455$.

35. Nakano Y, Asada K. Hydrogen peroxide is scavenged by ascorbate specific peroxidase in spinach chloroplasts. Plant Cell Physiol. 1981;22(5):867880 .

36. Kar M, Mishra D. Catalase, peroxidase, and polyphenoloxidase activities during rice leaf senescence. Plant Physiol. 1976;57(2):315-319.

37. Kaya C, Kirnak H, Higgs D. The effects of supplementary potassium and phosphorus on physiological development and mineral nutrition of cucumber and pepper cultivars grown at high salinity $(\mathrm{NaCl})$. Journal of Plant Nutrition. 2001a;24(1):285-294.

38. Huang Y, Bie Z, Liu Z, et al. Protective role of proline against salt stress is partially related to the improvement of water status and peroxidase enzyme activity in cucumber. Soil Sci Plant Nutr. 2009;55(5):698-704.

39. Agami RA. Applications of ascorbic acid or proline increase resistance to salt stress in barley seedlings. Biol Plant. 2014;58(2):341-347.

40. Teh CY, Noor CT, Shaharuddin A, et al. Exogenous proline significantly affects the plant growth and nitrogen assimilation enzymes activities in rice (Oryza sativa) under salt stress. Acta Physiologiae Plantarum. 2016;38(10):151

41. Wu GQ, Feng RJ, Li SL, et al. Exogenous application of proline alleviates salt-induced toxicity in Sainfoin Seedlings. J Anim Plant Sci. 2017;27(1):246-251

42. Akram MS, Ashraf M. Alleviation of adverse effects of salt stress on sunflower (Helianthus annuus L.) by exogenous application of potassium nitrate. J Appl Bot Food Qual. 2009;83(4):19-27.

43. Nounjan N, Nghia PT, Theerakulpisut P. Exogenous proline and trehalose promote recovery of rice seedlings from salt-stress and differentially modulate antioxidant enzymes and expression of related genes. Journal of Plant Physiology. 2012;169(6):596-604.

44. Nounjan N, Theerakulpisut P. Effects of exogenous proline and trehalose on physiological responses in rice seedlings during salt-stress and after recovery. Plant Soil Environ. 2012;1(7):309-315.

45. Wang M, Zheng Q, Shen Q, et al. The critical role of potassium in plan stress response. Int J Mol Sci. 2013;14(4):7370-7390.
46. Chen Z, Pottosin II, Cuin TA, et al. Root plasma membrane transporters controlling $\mathrm{K}^{+} / \mathrm{Na}^{+}$homeostasis in salt-stressed barley. Plant Physiol. 2007;145(4):1714-1725.

47. Cuin TA, Shabala S. Exogenously supplied compatible solutes rapidly ameliorate $\mathrm{NaCl}$-induced potassium efflux from barley roots. Plant Cell Physiol. 2005;46(12):1924-1933.

48. Assaha DVM, Ueda A, Saneoka $\mathrm{H}$, et al. The Role of $\mathrm{Na}^{+}$and $\mathrm{K}^{+}$ Transporters in SaltStress Adaptationin Glycophytes. Front Physiol. 2017;8:1-19.

49. Ben Ahmed C, Ben Rouina B, Sensoy S, et al. Exogenous proline effects on photosynthetic performance and antioxidant defense system of young olive tree. J Agric Food Chem. 2010;58(7):4216-4222.

50. Rong-Hua L, Pei-guo G, Baum M, et al. Evaluation of Chlorophyll Content and Fluorescence Parameters as Indicators of Drought Tolerance in Barley. Agric Sci China. 2006;5:751-757.

51. Abdelhamid MT, Rady MM, Osman AS, et al. Exogenous application of proline alleviates salt-induced oxidative stress in Phaseolus vulgaris L. Plants. J Hortic Sci Biotechnol. 2013;88(4):439-446.

52. Heuer B. Influence of exogenous application of proline and glycinebetaine on growth of salt-stressed tomato plants. Plant Sci. 2003;165:693-699.

53. Ashraf M, Foolad MA. Improving plant abiotic-stress resistance by exogenous application of osmoprotectants glycine betaine and proline. Environ Exp Bot. 2007;59:206-216.

54. Dubey RS, Pessarakli M. Physiological mechanisms of $\mathrm{N}$ absorption and assimilation in plants under stressful conditions. In: Pessarakli, M. editor. Hand book of Plant and Crop Physiology. Marcel Dekker: New York; 1995. p.605-625.

55. Zhang CS, Lu Q, Verma DPS. Characterization of 1-pyrroline-5carboxylate synthetase gene promoter in transgenic Arabidopsis thaliana subjected to water stress. Plant Science.1997;129(1):81-89.

56. Verma DP. Osmotic stress tolerance in plants: role of proline and sulfur metabolisms. In: Shinozaki K, Yamaguchi-Shinozaki, editors. Molecular Responses to Cold, Drought, Heat and Salt Stress in Higher Plants. Austin: RG Landes Company; 1999. p.153-168.

57. Zhao Y, Aspinall D, Paleg IG. Protection of membrane integrity in Medicago sativa (L). glycine betaine against the effects of freezing. $J$ Plant Physiol. 1992;140(5):541-543.

58. Valero E, Marcià H, De la Fuente IM, et al. Modeling the ascorbateglutathione cycle in chloroplasts under light/dark conditions. $B M C$ Systems Biolo. 2016;10:11. 